\title{
Using Imagination to Bridge Young Children's Literacy and Science Learning: A Dialogic Approach
}

\author{
Huili Hong, Karin Keith, Renee Rice Moran, and Jodi Lashay Jennings
}

\begin{abstract}
Huili Hong is an assistant professor in the Department of Curriculum and Instruction (CUAI) at East Tennessee State University's Claudius Clemmer College of Education. She coordinates CUAI's teacher education honours program and ESL endorsement program.Email: hongh1@etsu.edu

Also in CUAI at ETSU, Karin Keith chairs the department, Renee Rice Moran co-coordinates K-6 interdisciplinary educational studies, and Jodi Lashay Jennings is a clinical instructor.

Acknowledgement: This work was supported by a major grant from the Research Development Center of East Tennessee State University.
\end{abstract}

Integrating children's literacy and science learning has become a new focus in literacy instruction. Imagination, an integral part of children's learning experience, remains marginalized in today's early childhood education curriculum. Drawing on a yearlong ethnographic study in a first-grade classroom, this paper explores the potential affordance of imagination in integrating young children's literacy and science learning. The findings showed that the integration opportunities were organically constructed in and through children's natural engagement of imagination in their reading process. A dialogic approach is presented as one way to ignite children's imaginations in their literacy and science learning.

Keywords: imagination; children; literacy and science; dialogic pedagogy
Integrating children's learning of literacy and science has become a new focus in today's literacy instruction and learning (Cassidy et al., 2015). Children's acquisition and application of content area knowledge and literacy are fundamental to the work of new and future generations of professionals (Pearson et al., 2010; Yore et al., 2004). The idea of using imagination in children's literacy learning and practices has been embraced by numerous educational philosophers, researchers, and practitioners (Alcock, 2007; Cadwell, 1977; Dewey, 1902/1991, 1934, 1938; Dyson, 1997, 2003, 2006, 2014; Dyson \& Genishi,1993, 1994, 2009; Gallas, 2003; Greene, 2001; Heath, 1986; Isenberg \& Jalongo, 2014; Jalongo, 2004; McNamee, 2015; Paley, 1981, 1990, 2004; Rosenblatt, 1982, 2005; Vygotsky, 1978). Yet the role of imagination has remained marginalized in early childhood education and studies in the field. The purpose of this paper is to explore the potential affordance of imagination in bridging children's literacy and science learning through a dialogical approach, which we discuss below.

\section{Conceptualization of Imagination: Children's Inquiries into Play and Learning}

As researchers, teachers, and parents of children, we are always amazed by how imagination drives children's inquiries into play and various kinds of learning beyond the boundaries of their realistic worlds. As Lev Vygotsky noted (2004), the creative activity of children's imagination builds on, retains, reproduces, and constitutes the richness and variety of their personal experiences. Therefore, imagination is viewed in this study as an inseparable part of children's learning experiences. We also understand that children's imaginative play (or fantasy play) and playful or creative imagination are naturally combined in their daily life (Møller, 2015; Vygotsky, 2004). By natural combination, we mean children need imagination to make their play playful (Alcock, 2007) and to move their play beyond the existing play scenarios (Dewey, 1938). Meanwhile, children play to externalize and grow their imagination and creativity (Vygotsky, 1967). In this article, we link the concept of imagination to play, playful talk, and learning experiences. We focus on a positive role of imagination that can not only create an enjoyable learning atmosphere but also offer a space for transforming children' fantasy/imaginative play into exploratory learning opportunities. Based on the inherent link between children's imagination, play, talk, and learning experiences (Souto-Manning \& Martell, 2016; Vygotsky, 2004), we designed this study to capture the promising role of imagination and to explore the ways imagination can be used to bridge children's literacy and science learning. Overall, our research goals are twofold: first, to provide practical resources and empirical evidence from the classroom to help educators draw on children's imagination in their practice of integrating literacy and science learning; and second, to provide a better understanding of the inherent links among imagination, play, 
creativity, and learning.

\section{Imagination in Children's Literacy Learning}

Imagination is "a way of seeing and feeling things as they compose an integral whole and the large and generous blending of interest at the point where the mind comes in contact with the world" (Dewey, 1934, p. 267). Both Vygotsky (2004) and John Dewey (1938) posited that imagination as an experience can arouse curiosity, strengthen initiative, and set up desires and purposes. The idea of engaging children's imagination in literacy learning in both academic and social contexts is not new. Children's experience fuelled by imagination is a moving force for their continuous meaningful and joyful learning (Dewey, 1938). This philosophical idea about experience was reflected in Vygotsky's theory of mind (1978), in which imagination was related to the formation of abstract thought. Likewise, Louise Rosenblatt's $(1982,2005)$ transactional theory suggests that imagination is an inseparable component of readers' aesthetic experience in their response to texts and their meaning-making processes.

In The Ecology of Imagination in Childhood, Edith Cobb (1977) noted that "in childhood, the cognitive process is essentially poetic because it is lyrical, rhythmic, and formative in a generative sense; it is a sensory integration of self and environment" (p. 89). This integration, "the perceptual whole" in Dewey's (1938) words, occurs in and through imagination. Cobb (1977) further proposed that the poetic voice in our childhood is the root of adults' creativity, which is naturally tied to children's imagination. In this line of research associated with children's imagination, Don Holdaway (1979) based his classroom experiments in Auckland on the proposal that imagination is one of the operational factors affecting children's learning and use of written language. Similarly, Louise Boyd Cadwell's (1997) early work, which built on the Reggio Emilia approach (cf. Hewitt, 2001), documented the ways that children were more responsive to questions about things tied to their interests and imagination. Concentrating on children's writing, both Anne Dyson, alone (1997, 2003, 2006, 2014) and with Celia Genishi (1993, 1994, 2009), and Gillian McNamee (2015) have conducted studies demonstrating how imaginative storytelling can successfully engage children's personal interests and empower their writing.

The integration of literacy and science - the systematic study of the natural world based on facts learned through children's observation and experiments - not only draws on children's inborn needs of play and imagination, but also nurtures these needs and epistemological curiosity for new learning and knowledge (Campbell, 1957; Cobb, 1977). The value of playful imagination and imaginative play lies, not in the temporary affective response or impulse, but in what and where it moves toward and into (Dewey, 1938). Children's imagination often functions as a stimulus in their social interactions, causing a "ripple of ideas" among other participants (Paley, 1990, p. 21). In this sense, imagination is not only an individual cognitive process or a temporary affective impulse, but also a collective social process that can lead children into a new world of different voices, new visions, and other ways of expressing and exploring ideas (Paley, 1990, p. 34). In this way, it can be said that imagination affects children's ways of learning, using, doing, thinking of, and talking about literacies and science (Street, 1984, 1995) and consequently the forms and content of children's literacy practices (Black, 2009). Pearson (2014) also points out that science, literacy, and discourse are highly interrelated. Science is a contextualized academic language, creating a particular social context where language and literacies are employed as tools to talk, read, and write about the world and to observe, explore, and interact with the world. Therefore, the role of imagination can be illuminated in and through analysis of teacher-child interactive discourses in their literacy and science learning.

In An Imaginative Approach to Teaching, Kieran Egan (2005) puts imagination at the heart of effective teaching and learning. In this practice-oriented book, Egan introduces cognitive tools and provides a set of lesson plans and specific teaching strategies to help teachers activate children's imaginations and emotions in their literacy and content knowledge learning processes. However, there is a scarcity of experimental research on the role of imagination in the fusion of literacy and science or in other subject areas. Drawing on a yearlong ethnographic study in a first-grade classroom, this article attempts to extend this line of research by exploring opportunities of using imagination to integrate children's literacy and science learning in and through naturally occurring interactive classroom discourses.

\section{Logic of Inquiry}

This study is grounded in the application of social constructionism (Gergen, 1999, 2001), interactional sociolinguistics (Green \& Wallet, 1981; Gumperz, 1982; Hymes, 1974; Volosinov, 1929/1973), and discourse studies (Blommaert, 2005; Bloome et al., 2005) to the analysis of instructional conversations (Green \& Wallet, 1981). We also draw on Bakhtin's (1981) theoretical work, especially his assertion about the inherent dialogic nature of language. That is, any utterance is always a reflection and refraction of words that have been said before in and across different social contexts. This article views children's literacy and science learning not only as a set of literacy skills or scientific concepts but also as interpersonal social practices (Heath, 1983, 2012; Street, 1984, 1995). The site of 
children's literacy learning, meaning making, and content knowledge construction is therefore located in children's ongoing moment-tomoment social interactions, especially interactive discourses, which shape and are shaped by various social, cultural, and political factors (Bloome et al., 2005). In and through their social interactions, children often naturally and creatively juxtapose different texts, semiotic systems, imagination, play, and various personal experiences in their literacy learning (Bloome \& Hong, 2012; Bloome \& Robertson, 1993).

\section{Ethnography of Communication}

In light of our theoretical framework, we adopted an ethnographic approach to study the naturally occurring communications and social interactions between the teacher and children in a first-grade classroom over the course of an academic year. An ethnographic study is designed to allow researchers/observers to understand the studied community (here, the first-grade classroom), focusing on the members' activities, values, understandings, meaning construction process, and shared cultural models (cf. Gumperz, 1982; Hammersley \& Atkinson, 1995; Street, 1995). In our study, the teacher-child classroom interactions were guided by their conversational inferences dependent on their perceptions of verbal and nonverbal cues that contextualized their daily literacy practices (Gumperz, 1982). With an understanding of their co-constructed contextualization cues and shared cultural models, teachers and students can recognize their interactive discourses as a wider sequence of talk in which the local meaning in a certain social event may be referenced and thematically coherent with other local meanings created in other events (Cook-Cumperz, 2006). Therefore, with a yearlong time commitment, the inferential chain of meanings and understandings constructed in the teacher-child classroom interactions are visible and can be observed, understood, and described by the participant researchers (Cook-Gumperz, 2006).

\section{Ethnographic Data}

The yearlong ethnographic data collection took place in a first-grade classroom in Green Grass Elementary School (a pseudonym), a public elementary school in rural East Tennessee that serves communities of high poverty. Ninety-three percent of its students receive free or reduced-price meals. The study was part of a larger funded research project on the integration of literacy and content knowledge through a dialogical approach. Ms. Sterling was the teacher, and there were twenty children in her class. Ms. Sterling had approximately twenty years of teaching experience at the time of the study. She often started the school day with a morning routine of a short circle time for the children to talk about their stories or lives out of school, with some integration of math and science content. For example, they might discuss the weather or the number of days they had attended school so far in the year. Their mornings focused on reading and writing, followed by a lunch break. One hour in the afternoon was blocked for math, another for related arts. The children had a recess before the school dismissal.

The researchers made two to three visits to Ms. Sterling's class each week, usually spending the whole morning observing their reading and writing blocks as participants (DeWalt \& DeWalt, 2010; Spradley, 1980). During their observation hours, the researchers often had the opportunity to work with some struggling readers, writers, or English language learners (ELL) at the teacher's or the children's request. Field notes were taken, either during or after their visits. Both audio and video recordings were used to document the naturally occurring classroom interactions. The use of audio and video recording was dependent on the dynamics of the classroom activities on each particular day. Ms. Sterling was interviewed twice. The first interview took place in the first professional development workshop that was offered to all of the teachers who participated in the large research project (including Ms. Sterling) in the fall semester. It focused on the teachers' language uses and word choices. The second interview was administered in Ms. Sterling's classroom at the end of the academic year. Children's artifacts and classroom documents were collected during the course of the yearlong research project. Data analytic and reflection memos were kept during the data collection and analysis processes. Data selected for this article included the second interview with Ms. Sterling about the integration of literacy and science, an audio segment of a routine interactive read-aloud session in the classroom, field notes, and artifacts from the second professional workshop offered in the spring semester.

\section{Discourse Analysis of Ethnographic Data}

Drawing on the theoretical framework outlined above and the ethnographic approach (Bakhtin, 1986; Freire, 1970; Wells, 1999), we adopted discourse analysis to capture the complexities of children's orchestration of imagination, play, talk, literacy learning, and various life experiences (Bloome et al., 2005). Doing so aims to demonstrate imagination as a possible way to engage the children into more creative, meaningful, and joyful learning, to integrate their literacy and science learning, and to alleviate boredom through connecting their schooling and various life experiences (Dewey, 1938; Fredricks, Blumenfeld, \& Paris, 2004; Paley, 2004; Rowe \& Neitzel, 2010; Schlechty, 2002; Smith et al., 2001; Vibert \& Shields, 2003; Wholwend, 2015). 
To illustrate how opportunities of using imagination to blend literacy and science can be identified and/or constructed in children's daily schooling, we focused our discourse analysis on the ethnographic data of the naturally occurring teacher-child classroom interactions, especially their natural engagement of imagination (Bloome et al., 2005; Green \& Wallet, 1981; Gumperz, 1982). More specifically, key literacy events (cf. Heath, 1982) that involved the engagement of children's imagination and/or the existing or potential opportunities of integrating their literacy and science learning were identified as primary analytic units. In this article, two particular literacy events are highlighted based on this rationale. One was part of Ms. Sterling's reflection in the second interview about the challenges, opportunities, and benefits of integrating science into her class's current curriculum; the other was a teacher-child interactive "read-aloud," which was part of and should appropriately represent the first graders' daily literacy practices. The teacher-child discourses in the selected key events were transcribed and then microanalyzed (Bloome et al., 2005, 2008; Green \& Wallet, 1981) to examine the social interactional functions of their talk and to explore the opportunities of using imagination to blend literacy and science learning in and through their interactive discourses. To incorporate the participants' understandings of the selected literacy events and the broader social contexts in the inferencing of their meaning making and imagination experience (Schiffrin, 1996), the researchers obtained an emic/insider's perspective of what was really going on in the classroom through their yearlong participant observation (DeWalt \& DeWalt, 2010; Spradley, 1980). Moreover, discourse analysis was triangulated with qualitative analysis (cf. Maxwell, 2004) of the interviews with the teacher, the researchers' observational field notes, and the children's artifacts.

\section{Integration of Literacy and Science: Needs and Challenges}

Prior to exploring the opportunities of using imagination to integrate children's literacy and science learning, we first investigated the challenges the teacher encountered in her teaching practice. In the selected interview data, Ms. Sterling discussed with us her comfort level in teaching science and mathematics in her class. The following excerpt (1) is drawn from the interview transcript.

\section{Excerpt 1}

Ms. Sterling: Well, you know, math definitely stronger than science, simply because I've got the cut, clearcut standards, and, you know, it's a time during the day that has to be done, you know. The science, I don't have a problem with teaching it, but quite honestly, I don't even know if I have a copy of the most recent standards, and we've heard, you know, when we had that meeting, that last meeting we did with the activities, I had to say, what is STEM again? Because I've heard of it, but we've not been talked to about it. You know, we've had no training in it, we've not been given, other than the resources you gave us, we've not been given any resources. And we flat out have been told: reading and math, reading and math, teach your science and social studies through the reading. Which we are doing more of, because of the nonfiction component of common core (the new standards are widely adopted in the U.S.). It is definitely easier to do that, our basal even, I just use it for shared reading, but it lends itself to that, but it's the hands on, beyond the discussion, finding the time to do that, because it's certainly not in the day's schedule, so, um, because I'm not doing as much of the science as math, I'd probably say that my level of comfort is lower...

It is revealed in Ms. Sterling's response that there have been needs as well as challenges in integrating science into elementary teachers' (like Ms. Sterling and our other participant teachers) daily schedule or the curriculum, which has an overt emphasis on reading and math. Many teachers, like Ms. Sterling, have become aware of this new integration trend in literacy instruction, but have not received much relevant professional training. Lack of resources and the more stringent curriculum are also obvious factors affecting the integration of science in their daily teaching. Meanwhile, Ms. Sterling saw the importance of the interdisciplinary correlation and proposed the idea of teaching science and social studies through the reading curriculum.

\section{Integration of Literacy and Science: Professional Development and Resources}

In an effort to turn the challenges and the teachers' ideas into possibilities, we offered a professional development (PD) workshop to our six participant teachers in their school library after school. This PD workshop sought to help the teachers learn how to integrate science with reading / language arts and create a space for their students to engage their playful imaginations into their learning through playful hands-on activities and projects (Vygotsky, 1978, 2004). In this workshop, we proposed (a) that the elementary years are crucial for building children's love of scientific learning and opening their eyes to the possibilities of science (Bradbury, 2013; National Research Council, 2012) and (b) that content knowledge needs to be integrated with reading and language arts so that children can have an idea 
about how reading and writing serve as tools that facilitate thinking and make disciplinary literacy and content knowledge learning visible and feasible.

We set up three hands-on activity stations and divided the teachers into three pairs who worked collaboratively and rotated through each station. The teachers were provided with the award-winning Picture-Perfect Science Lessons series published by the National Science Teachers Association (Ansberry \& Morgan, 2007, 2010; Morgan \& Ansberry, 2013). We adopted some of the ideas and activities from the books and let the teachers explore the science topics through observing, data recording, and solving the problems. After the workshop, the teachers were provided with a banker's box that included books of science lessons, a list of all the materials needed in each science station, a set of multilevelled fiction and nonfiction texts on the selected science topics, and some basic materials to start their own science stations. (See the sidebar for resources used in the bubble station.)

After receiving the professional training and resources, Ms. Sterling blocked a time and tried to integrate some science activities into her literacy blocks. In our interview (Excerpt 2), when we asked her how the workshop and resources had helped her or the children, Ms. Sterling mentioned a few times that integration was possible and desirable, and that the children loved the activities.

\section{Excerpt 2}

Ms. Sterling: Oh everybody, yeah, and plus they loved it, and they really, it really helped their cooperativeness and working together too, so it's definitely something that I want to do again ...

\section{Bubble Station Resources}

- Bubble blowers (shapes of flowers, hearts, stars, squares, circles, etc.)

- Cups

- Measuring cups

- Straws

- Cut-outs of books titles

- Liquid bubbles

- Two circle platters

- Books

Shapes

Shapes in Sports

- What Shapes Do You See?

- Shapes in the Kitchen

Shapes in Music

- Shapes in Buildings

- Shapes in the Garden

- The Shape of Things

- Bubble Trouble

- Bubble Bubble

- Pop! A Book About Bubbles

- How to Make Bubbles

Bubbles Float, Bubbles Pop

- Index cards with math sentences on them (ex. 6+5)

- Construction paper with words in boxes (ex. hat, mat, rat)

Ms. Sterling: ... so if something could be done that went along with the reading and language arts standards so that we're kind of killing two birds with one stone, that would be really really effective, and to make it even better, if it could correlate somehow with some of our basal reading stories...

Ms. Sterling: And I correlate as much as I can, but yeah, anything to correlate and bring it together I just think is valuable.

Based on the findings about Ms. Sterling's successful experiment with an integrated approach in her class and her realization of the importance and benefits of it, we then focused our data analysis on how imagination can be engaged and used to organically fuse children's literacy and science learning in and through the naturally occurring interactive classroom discourses.

\section{Integration of Literacy and Science: The Role of Imagination}

To explore the opportunities of integrating literacy and science learning in organic and seamless ways, we decided to conduct an in-depth micro-level discourse analysis of the moment-to-moment teacher-child classroom interactions. The following literacy event (Excerpt 3 ) was found to be a powerful demonstration of using imagination to organically integrate children's science learning and literacy practices. This conversation was audio-recorded in Ms. Sterling's routine morning reading block. The learning goals or target reading skills and 
strategies set for that day (summarizing, retelling, sequencing, and asking and answering questions) were written on the whiteboard at the front of the classroom. Ms. Sterling also explicitly stated the goals.

\section{Excerpt 3}

1. Teacher: And you are correct. The main character is Santa. And the title of our story today is The Bubble Gum Christmas.

2. Children: Christmas.

3. Children: Oooooh.

4. Teacher: And as you listen, I want you to think about what happens at the beginning,

5. Selina: middle and end

6. Teacher: or the first of the story. Then what happens, next what happens, and last what happens.

7. Selina: and next what's like

8. Teacher: In case we had an extra one. It was Christmas, tap, tap, tap. The elves worked. They chew, chew, chewed. The elves chewed. They chewed bubble gum. They made bubble gum. Chew, chew, chew, the elves chewed. "Chew and Puff," said Santa. "Are you working? Are you" ....

9. Children: Playing

10. Teacher: They are playing by doing what?

11. Children: Blowing

12. Teacher: Blowing bubbles and they are working by doing what?

13. Children: Working

14. Selina: = and tapping

15. Teacher: Tapping and building what?

16. Joe: Toys

17. Children: Toys

18. Selina: Maybe they are just testing the bubble gum.

19. Joe: Yeah probably.

20. Teacher: "We are working," said the elves. "We are making toys. We are playing too. We are making bubbles."

21. Joe: [Did I see nutcrackers?]

22. Teacher: = So they were doing two things, weren't they?

23. John: [I thought $x x x x$, I thought, me too.]

24. Teacher: = "Look, look," said one elf. "See my bubble? See my big bubble?" "I like bubbles," said Santa. "I will chew gum. I will make bubbles too."

25. Selina: are there any like=

26. Teacher: Chew, chew, chew. Santa chewed. Puff, puff, the bubble was bigger.

27. Selina: Uh-oh, pop.

28. Teacher: Puff, puff, POP! Santa's big bubble popped.

29. Children: NO!

30. Teacher: Put your hand up if you have gotten gum in your hair.

31. Selina: I got it all around my lips $x x x x$.

32. Teacher: It's very hard to get it out [isn't it]?

33. Children: [Oh, yes it is. ]

34. Children: [l know! ]

35. Christian: Ms. Sterling, my mom had to cut it.

36. Children: Ms. Sterling!

37. Teacher: She had to cut it?

38. Emma: My mom had to [cut it too.]

39. Children: [xxxx]

40. Joe: I just got, I just got some gum on my blanket.

41. Teacher: =So who thinks they can make a prediction, how is Santa going to get the gum out of his beard?

42. Children: inhale.

43. Eli: $\quad$ Could be cutting

44. Children: Ooooo

45. Children: Cutting 
46. Teacher: Emma what do you think? Do you think he's going to cut it off? Does anyone have

47. Nelson, what he might do? a different prediction as to what he might do? Jason, what do you think he might do?

48. Jason: The reindeers can chew it off.

49. Children: [@@@@]Eww.

50. Teacher: That's a good prediction. What do you think, Alice?

51. Alice: Hot water get it off.

52. Christian: Put carrot, put carrots all over it let's xxx own...

53. Joe: Reindeer

In Excerpt 3, Ms. Sterling started the teacherchild interactive read-aloud mixed with a series of questions that aimed to help the children acquire the target reading skills and strategies (summarizing, retelling, sequencing, and asking and answering questions). The children successfully identified the main character and sequenced the story events in their echoing or immediate retelling. The teacher-child questioning and answering became more enjoyable and seemingly off-task conversations occurred when they began to talk about "testing of the bubble gum" (line 18), chewing gum, and popping the bubble. The opportunity to use imagination to integrate science and literacy learning emerged on line 30 , when the teacher asked the children to "put your hand up if you

\begin{tabular}{|c|l|}
\hline$=$ & Transcription Conventions \\
& $\begin{array}{l}\text { Latching (i.e., very short pause, } \\
\text { almost overlapped talking) }\end{array}$ \\
\hline$[\ldots]$ & Overlapped talking \\
\hline $\mathrm{xxxx}$ & inaudible talking \\
\hline$\downarrow$ & Falling tone \\
\hline$\uparrow$ & Rising tone \\
\hline CAPITAL LETTERS/SOUNDS & stressed letter/sound \\
\hline$(0.3)$ & pause \\
\hline ... $_{2}$ & Long pause (time length) \\
\hline$\ldots$ & (Accelerated speaking speed) \\
\hline$@$ & Incomplete talk \\
\hline lo::ve: & Laugh \\
\hline & elongated sound \\
\hline
\end{tabular}

have gotten gum in your hair." This question obviously excited the children and catalyzed their active sharing of their lived experiences of getting bubble gum all around their lips and into their hair, cutting it off from their hair, and getting it on their blanket. Ms. Sterling skilfully grasped the opportunity to strengthen the children's prediction skills (line 41) through asking them to predict how Santa was going to get the gum off his beard.

The teacher's question on line 41 indeed sparked the children's imaginations, which successfully engaged the children in their learning process. The children began to make various connections between their reading and their lived or imagined experiences: They suggested cutting the gum off, using hot water, putting carrots all over it, and letting the reindeer chew it off. Their reaction to the teacher's question and their peers' sharing of ideas occurred in a way similar to that described by Vivian Paley (1990): "Friendship and fantasy form the natural path that leads children into a new world of other voices, other views, and other ways of expressing ideas and feelings they recognize as similar to their own" (p. 34). What is more important, when children's ideas find a nurturing environment, they will grow naturally out of the children's playful imagination, unfold from the children's imaginative play, thrive, and develop into inquiry learning and actions (Dewey, 1902/1991; Paley, 1990; Vygotsky, 2004). In the above excerpt, the children's ideas and the images came to them, not by the set purpose or goals, but in intense and illuminating flashes; they can only move closer to actuality by coming up with plans and actions (Dewey, 1934, p. 276). Therefore, children's imagination, play, talk, improvised ideas, and science inquiry can and need to be completely fused (p. 276) to move these temporary impulses into deeper learning and exploration. In Ms. Sterling's class, the children's engagement with their imaginations, personal experiences, and ideas that grew out of the interactive read-aloud process were used to construct an authentic task of solving a meaningful real-life problem: how to remove bubble gum from different things mentioned in their conversation or in their further reading of other texts. This scenario encapsulates child-driven inquiry at its best. How to remove bubble gum, as a unique state of matter, can be an interesting, authentic, child-friendly project for the children to explore and negotiate while they construct their understanding of scientific concepts and deepen their academic literacy learning.

\section{Excerpt 4}

Teacher: = Gum is on your beard, said the elves.

Alice: Oh, my GOODNESS!

Teacher: = You mu::st 


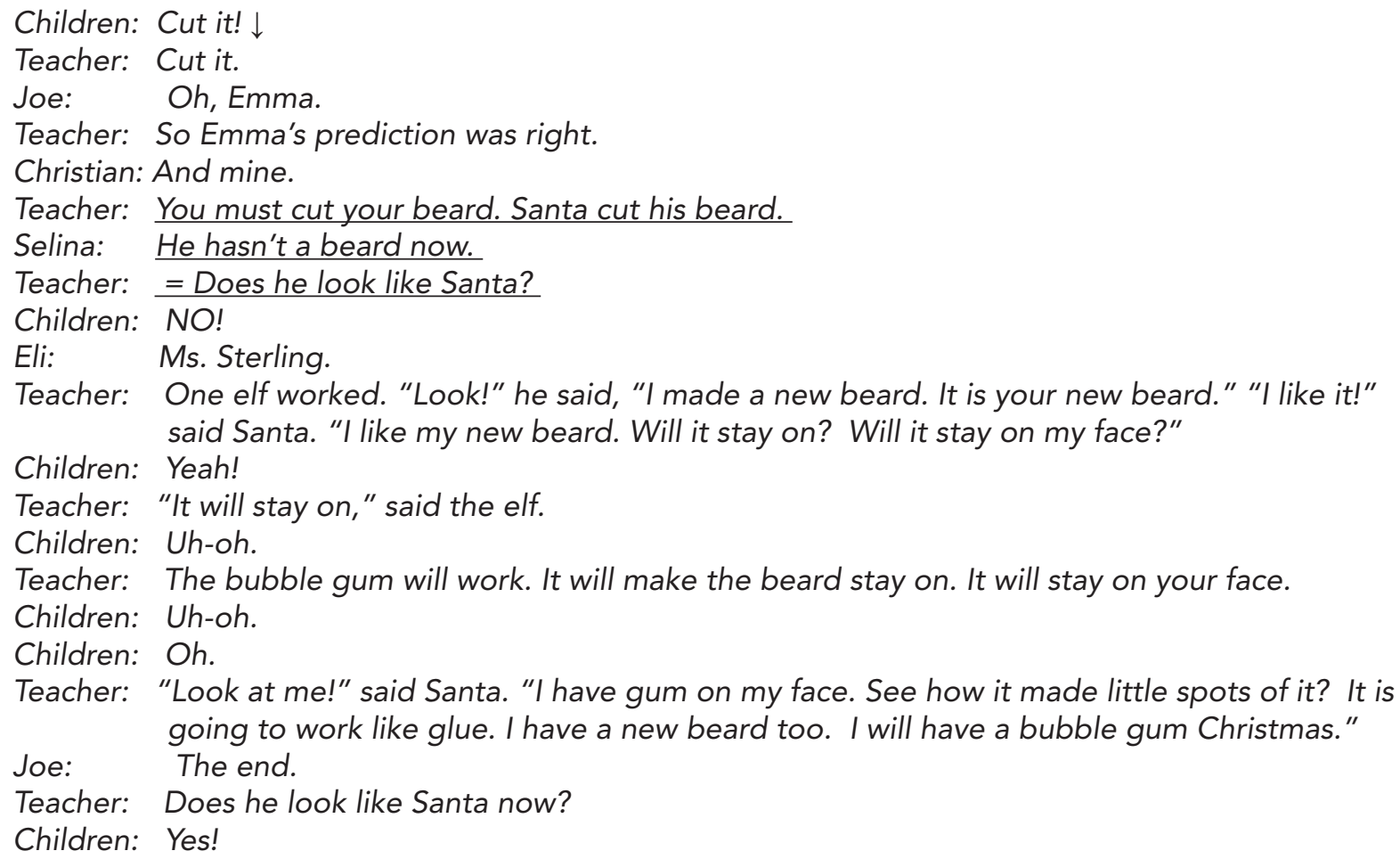

Excerpt 4 reveals another opportunity for using imagination to fuse children's personal experience (in and out of school, realistic and imaginative) with literacy and science learning. The second potential opportunity is located between lines 9 and 12 of the excerpt, when the children realized that Santa would not look like Santa without his beard. This was an opportunity to apply the children's existing literacy skills and content knowledge in a different situation. The teacher-child dialogic process here can be purposefully geared toward using this opportunity to recontextualize the children's content knowledge and disciplinary literacy skills through their further investigation of possible materials other than gum that can put Santa's beard back and make him look like Santa again.

Through exploring the potential opportunities afforded by the children's engagement of imagination in their daily school literacy practices, we demonstrated and confirmed the ideas that the occurrence of impulse (like the children's natural engagement of imagination) should not be seen as an end in itself but an opportunity and a call for scientific inquiry for new knowledge and learning in and across different disciplines (Dewey, 1938; Vygotsky, 2004). As teachers and teacher educators, our job is to help the teachers and children see when, where, and how opportunities to fuse literacy and science learning can be discursively constructed and taken advantage of through a new lens to see and understand the role of imagination in the integrated instructional trend.

\section{Conclusion}

In this article, we investigated the challenges that the teachers of young children usually face in integrating literacy and science in their teaching practice. Based on our findings about these challenges, we provided practical resources and empirical evidence from the focus first-grade classroom to show how teachers may draw on children's playful imagination and/or imaginative play to identify and construct opportunities to integrate children's literacy and science learning. Analysis of the interview with Ms. Sterling revealed that the professional training and resources provided in this project made science teaching and "correlating science and literacy together" possible, exciting, and beneficial to Ms. Sterling's students. This finding led our data analysis into an in-depth discourse analysis of the teacher-child interactive discourses in their routine reading workshop. The micro-level discourse analysis made visible potential opportunities for using imagination in a more organic integration of science and literacy learning, which is known as whole language learning for children (Goodman, 1986; Piaget, 1955; Weaver, 1990).

Our overall data analysis results showed and reaffirmed the inherent links among children's imagination, play, curiosity, creativity, and learning. Our findings support the notion that children, through their playful imagination and imaginative play, can naturally bring their various personal and cultural experiences into the integration of science and literacy learning processes and practices (Dewey, 1938; 
Piaget, 1955; Vygotsky, 1978, 2004). To use the children's predictions of ways to remove gum from Santa's beard or different things as an example, opportunities of integrating literacy and science learning were creatively and discursively constructed through engaging children's playful imaginations, their natural drive to play and explore, and their memories of prior life experiences. Such opportunities need be taken up to support children's scientific inquiries for new content knowledge and academic learning through their voluntary application of literacy skills in a cross-disciplinary context. This inquiry process, fuelled by children's imagination, curiosity, and inborn play drive, can not only foster and sharpen their scientific noticing (Campbell, 1957) but also scaffold their reading, writing, and disciplinary literacy learning (Hong, in press).

Based on our findings, we argue for the critical importance of a dialogic approach in igniting children's imaginations. In particular, this dialogic approach highlights the centrality of oracy as well as the importance of oral language and the utilization of oral languages. Teachers need to optimize the developing or well-developed oracy that young children bring to early schooling. Doing that can make possible a gentle support movement back and forth between children's oracy and literacy in and across different content areas and life domains. Furthermore, this approach can redefine the teacher-child social and power relationship in new ways that can build and strengthen children's active agency in releasing and engaging their imagination in the acquisition of academic literacies. Therefore, we would like to invite teachers to see two things: (1) that opportunities to use imagination to promote children's academic literacy learning naturally grow out of their daily classroom interactions, where the children can find or be led to paths that connect their current learning with various personal experiences; and (2) if the precondition that the children are able to make meaningful connections between their learning and personal experience is met, imagination can become the driving force for children's active exploration of interesting unknowns and their voluntary application of literacy skills in different realistic or imagined unknown ("what-if") situations. Thereupon, their active inquiry process will result in children's more self-directed learning and acquisition of new content knowledge and academic literacies. Then, the new knowledge, skills, and experience the children obtained during the inquiry process will, in return, fertilize the ground for the further growth of children's imagination and influence the formation of their learning purposes and attitudes toward schooling (Dewey, 1938, p. 34). That is, engaging imagination in children's integrated literacy and science learning is a continuous spiral process (Dewey, 1938, p. 97). For us and for teachers, it is also important to know the range of our students' capabilities, which can be scaffolded to construct and reconstruct their various experiences in their learning process. A good knowledge of our students' capabilities will let us be more sensitive to when, where, and how children's imaginations can be freed and used to fuel their academic learning in and across different disciplines.

\section{References}

Alcock, S. (2007). Playing with rules around routines: Children making mealtimes meaningful and enjoyable. Early Years, 27(3), 281-293.

Ansberry, K., \& Morgan, E. (2007). More picture perfect science lessons. Arlington, VA: National Science Teachers’ Association.

Ansberry, K., \& Morgan, E. (2010). Picture perfect science lessons (2 ${ }^{\text {nd }}$ ed.). Arlington, VA: National Science Teachers' Association.

Bakhtin, M. (1981). The dialogic imagination: Four essays. Austin, TX: University of Texas Press.

Black, R. W. (2009). Online fan fiction, global identities, and imagination. Research in the Teaching of English, 43(4), 397-425.

Bloome, D., Carter, S. P., Christian, B. M., \& Madrid, S. (2008). Discourse analysis in classrooms: Approaches to language and literacy research. New York, NY: Teachers College Press.

Bloome, D., Carter, S. P., Christian, B. M., Otto, S., \& Shuart-Faris, N. (2005). Discourse analysis and the study of classroom language and literacy events: A microethnographic perspective. Mahwah, NJ: Lawrence Erlbaum.

Bloome, D., \& Egan-Robertson, A. (1993). The social construction of intertextuality in classroom reading and writing lessons. Reading Research Quarterly, 28(4), 305-333.

Bloome, D., \& Hong, H. (2013). Reading and intertextuality. In C. A. Chapelle (Ed.), The encyclopedia of applied linguistics. New York, NY: John Wiley \& Sons. 
Cadwell, L. B. (1997). Bringing Reggio Emilia home: An innovative approach to early childhood education. New York, NY: Teachers College Press.

Campbell, N. R. (1957). Science, imagination, and art. Science, 125(3252), 803-806.

Cassidy, J., Grote-Garcia, S., \& Ortlieb, E. (2015). What's hot in literacy survey 2016: The process. Literacy Today, 33(2), $22-27$.

Cobb, E. (1977). The ecology of imagination in childhood. Dallas, TX: Spring Publications.

Cook-Gumperz, J. (2006). The social construction of literacy ( $2^{\text {nd }}$ ed.). New York, NY: Cambridge University Press.

DeWalt, K. M., \& DeWalt, B. R. (2010). Participant observation: A guide for fieldworkers (2 ${ }^{\text {nd }}$ ed.). Lanham, MD: AltaMira Press.

Dewey, J. (1902/1991). The school and society and the child and the curriculum. Chicago, IL: University of Chicago Press.

Dewey, J. (1934). Art as experience. New York, NY: Minton, Balch, \& Company.

Dewey, J. (1938). Experience and education. New York, NY: Macmillan.

Dyson, A. H. (1997). Writing superheroes: Contemporary childhood, popular culture, and classroom literacy. New York, NY: Teachers College Press.

Dyson, A. H. (2003). The brothers and sisters learn to write: Popular literacies in childhood and school cultures. New York, NY: Teachers College Press.

Dyson, A. H. (2006). On saying it right (write). Research in the Teaching of English, 4l(1), 8-39.

Dyson, A. H. (2014). ReWRITING the basics: Literacy learning in children's cultures. New York, NY: Teachers College Press.

Dyson, A. H., \& Genishi, C. (1993). Visions of children as language users: Language and language education in early childhood. In B. Spodek (Ed.), Handbook of research in the education of young children (pp. 122-136). New York, NY: Macmillan.

Dyson, A. H., \& Genishi, C. (1994). The need for story: Cultural diversity in classroom and community. Urbana, IL: National Council of Teachers of English.

Dyson, A. H., \& Genishi, C. (2009). Children, language, and literacy: Diverse learners in a diverse society. New York, NY: Teachers College Press.

Egan, K. (2005). An imaginative approach to teaching. San Francisco, CA: Jossey-Bass.

Fleer, M. (2013). Affective imagination in science education: Determining the emotional nature of scientific and technological learning of young children. Research in Science Education, 43, 2085-2106.

Fredricks, J. A., Blumenfeld, P. C., \& Paris, A. H. (2004). School engagement: Potential of the concept, state of the evidence. Review of Educational Research, 74, 59-109.

Freire, P. (1970). Pedagogy of the oppressed. New York, NY: Continuum.

Gallas, K. (2003). Imagination and literacy: A teacher's search for the heart of learning. New York, NY: Teachers College Press.

Goodman, K. S. (1986). What's whole in whole language?: A parent/teacher guide to children's learning. Portsmouth, NH: Heinemann.

Green, J. L., \& Wallet, C. (1981). Mapping instructional conversations: A sociolinguistic ethnography. In J. L. Green \& C. Wallet (Eds.), Ethnography and language in educational settings (pp. 161-207). Norwood, NJ: Ablex. 
Greene, M. (2001). Variations on a blue guitar: The Lincoln Center Institute lectures on aesthetic education. New York, NY: Teachers College Press.

Gumperz, J. J. (1982). Discourse strategies. New York, NY: Cambridge University Press.

Hammersley, M., \& Atkinson, P. (1995). Ethnography: Practices and principles. New York, NY: Routledge.

Heath, S. B. (1986). Separating "things of the imagination" from life: Learning to read and write. In W. H. Teale \& E. Sulzby (Eds.), Emergent literacy: Writing and reading (pp. 156-172). Norwood, NJ: Ablex.

Hewitt, V. (2001). Examining the Reggio Emilia approach to early childhood education. Early Childhood Education Journal, 29(2), 95-100.

Holdaway, D. (1979). The foundations of literacy (Vol. 138). Sydney, Australia: Ashton Scholastic.

Hong, H. (in press). Writing as defamiliarization processes: An alternative approach to understanding aesthetic experience in young children's poetry writing. Journal of Early Childhood Literacy.

Isenberg, J. P., \& Jalongo, M. R. (2014). Creative thinking and arts-based learning: Preschool through fourth grade (6 ${ }^{\text {th }}$ ed.). London, England: Pearson Higher Education.

Jalongo, M. R. (2004). Young children and picture books. Washington, DC: National Association for the Education of Young Children.

Maxwell, J. (2004). Qualitative research design: An interactive approach. Thousand Oaks, CA: SAGE.

McNamee, G. D. (2015). The high performing preschool: Story acting in Head Start classrooms. Chicago, IL: University of Chicago Press.

Møller, S. J. (2015). Imagination, playfulness, and creativity in children's play with different toys. American Journal of Play, 7(3), $322-346$.

Morgan, E., \& Ansberry, K. (2013). Picture perfect science lessons, K-5. Arlington, VA: National Science Teachers' Association.

Paley, V. G. (1981). Wally's stories: Conversations in the kindergarten. Cambridge, MA: Harvard University Press.

Paley, V. G. (1990). The boy who would be a helicopter: The uses of storytelling in the classroom. Cambridge, MA: Harvard University Press.

Paley, V. G. (2004). A child's work: The importance of fantasy play. Chicago, IL: University of Chicago Press.

Pearson, P. D. (2014). Science and literacy: Better together: Each in the service of the other. [PowerPoint slides]. Retrieved from: http:// www.scienceandliteracy.org/research/pdavidpearson

Pearson, P. D., Moje, E., \& Greenleaf, C. (2010). Literacy and science: Each in the service of the other. Science, 328(5977), 459-463.

Piaget, J. (1955). The language and thought of the child. New York, NY: The New American Library.

Rosenblatt, L. M. (1982). The literary transaction: Evocation and response. Theory into Practice, 21(4), 268-277.

Rosenblatt, L. (2005). Making meaning with texts: Selected essays. Portsmouth, NH: Heinemann.

Rowe, D. W., \& Neitzel, C. (2010). Interest and agency in two- and three-year-olds' participation in emergent writing. Reading Research Quarterly, 45(2), 169-195. 
Schlechty, P. C. (2002). Working on the work: An action plan for teachers, principals, and superintendents. San Francisco, CA: JosseyBass.

Smith, W. J., Donahue, H., \& Vibert, A. B. (Eds.) (2001). Student engagement in learning and school life: Case reports from project schools (Vols. 1 \& 2). Montreal, QC: Ed-Lex, Faculty of Law, McGill University.

Souto-Manning, M., \& Martell, J. (2016). Reading, writing, and talk: Inclusive teaching strategies for diverse learners, $K-2$. New York, NY: Teachers College Press.

Spradley, J. (1980). Participant observation. Orlando, FL: Harcourt College.

Street, B. (1984). Literacy in theory and practice. New York, NY: Cambridge University Press.

Street, B. (1995). Social literacies. London, England: Longman.

Vygotsky, L. S. (1967). Play and its role in the mental development of the child. Soviet Psychology, 5(3), 6-18.

Vygotsky, L. S. (1978). Mind in society: The development of higher psychological processes. Cambridge, MA: Harvard University Press.

Vygotsky, L. S. (2004). Imagination and creativity in childhood. Journal of Russian \& East European Psychology, 42(1), 7-97.

Weaver, C. (1990). Understanding whole language. Portsmouth, NH: Heinemann,

Wells, G. (1999). Dialogic inquiry: Towards a sociocultural practice and theory of education. Cambridge, England: Cambridge University Press.

Wohlwend, K. E. (2015). Playing their way into literacies: Reading, writing, and belonging in the early childhood classroom. New York, NY: Teachers College Press.

Yore, L. D., Hand, B. M., \& Florence, M. K. (2004). Scientists' views of science, models of writing, and science writing practices. Journal of Research in Science Teaching, 41(4), 338-369. 